\title{
PEMBERIAN Lactobacillus Sp. DAN INULIN DARI UMBI DAHLIA TERHADAP KECERNAAN LEMAK DAN MASSA LEMAK TELUR PADA AYAM KEDU PETELUR (Feeding Lactobacillus sp. and Inulin from Dahlia Tuber on Fat Digestibility and Egg Fat Mass in Kedu Hen)
}

\section{Ika Luciana Widia Astuti, Istna Mangisah, Nyoman Suthama}

Fakultas Peternakan dan Pertanian Universitas Diponegoro Kompl.Drh. R. Soejono Koesoemowardojo-Tembalang, Semarang 50275 Email: ikaluciana709@gmail.com

\begin{abstract}
ABSTRAK
Penelitian bertujuan untuk mengkaji pengaruh pemberian kombinasi Lactobacillus $s p$. dan inulin dari tepung umbi dahlia terhadap kecernaan lemak kasar, lemak abdominal dan massa lemak telur pada ayam Kedu. Penelitian menggunakan rancangan acak lengkap (RAL) dengan 4 perlakuan dan 5 ulangan. Perlakuan yang diberikan yaitu $\mathrm{T} 1=$ ransum peternak, $\mathrm{T} 2=$ ransum perbaikan, $\mathrm{T} 3=\mathrm{T} 1+1,2 \mathrm{~mL}$ Lactobacillus $\mathrm{sp}$. dan 1,2\% unulin dari umbi dahlia, T4 $=\mathrm{T} 2+1,2 \mathrm{~mL}$ Lactobacillus sp. dan 1,2\% inulin dari umbi dahlia. Ternak yang digunakan adalah 80 ekor ayam Kedu betina fase layer berumur 7 bulan. Parameter yang diamati yaitu kecernaan lemak kasar, lemak abdominal dan massa lemak telur. Hasil penelitian menunjukkan bahwa penambahan Lactobacillus sp. dan inulin tepung umbi dahlia berpengaruh nyata $(\mathrm{P}<0,05)$ terhadap kecernaan lemak kasar dan massa lemak telur, tetapi tidak terhadap lemak abdominal. Kesimpulan penelitian adalah pemberian 1,2 $\mathrm{mL}$ Lactobacillus sp. dan 1,2\% inulin dari umbi dahlia baik pada ransum peternak maupun ransum perbaikan mampu menurunkan massa lemak telur, meskipun dengan kecernaan lemak sama.
\end{abstract}

Kata kunci: Lactobacillus sp., umbi dahlia, kecernaan lemak, massa lemak telur, ayam Kedu petelur

\section{ABSTRACT}

The present research was aimed to evaluate feeding effect of a combination of Lactobacillus sp. and inulin from dahlia tuber powder on fat digestibility, abdominal fat and egg fat mass. The experiment was assigned in a randomized complete design (CRD) with 4 treatments and 5 replications. The treatments applied were $T 1=$ farmer ration, $T 2$ $=$-improved ration, $T 3=T 1+1,2 \mathrm{~mL}$ Lactobacillus $s p$. and 1.2\% dahlia tuber powder, $T 4$ $=T 2+1,2 \mathrm{~mL}$ Lactobacillus sp. and 1.2\% dahlia tuber powder. Experimental animals were 80 birds of Kedu hen of 7 months old with initial body weight was $1300 \pm$ 229,92g. Parameters observed were fat digestibility, abdominal fat and egg fat mass. The results showed that feeding Lactobacillus sp. and inulin of dahlia tuber powder significantly $(P<0,05)$ affected fat digestibility and fat mass of eggs, but there was no effect on abdominal fat. Conclusion is that dietary inclusion of 1,2 mL Lactobacillus sp. 
and 1,2\% dahlia tuber powder both in farmer ration and improved ration can decreases egg fat mass with the same fat digestibility.

Keywords: Lactobacillus sp., dahlia tubers, fat digestibility, egg fat mass, Kedu hen.

\section{PENDAHULUAN}

Unggas lokal seperti misalnya ayam Kedu dapat dikembangkan untuk memperkuat ketahanan pangan daerah dengan memanfaatkan produksi daging dan telur. Ayam Kedu termasuk jenis unggas lokal yang populer dikalangan masyarakat karena memiliki karakteristik yang spesifik dengan beberapa keunggulan dibandingkan dengan ayam kampung lainnya.Ayam Kedu memiliki produksi telur dan pertumbuhan yang lebih tinggi jika dibandingkan dengan jenis ayam lokal lainnya, namun lebih rendah dibanding ayam ras. Kemampuan produksi ayam Kedu dapat ditingkatkan dengan pemberian ransum yang memenuhi kebutuhan. Upaya pemenuhan kebutuhan nutrien dapat dilakukan dengan perbaikan kualitas ransum. Bahan additif juga perlu diberikan untuk membantu peningkatan efisiensi nutrien sehingga berdampak pada perbaikan produktivitas. Penambahan bahan additifbersifat alami yang tidak mempunyai efek negatif bagi konsumen berupa prebiotik atau probiotik ataupun gabungan antara keduanya yang dapat diberikan bersama dengan perbaikan ransum.

Fungsi prebiotik sebagai sumber "makanan" bagi mikroba yang menguntungkan. Jenis prebiotik yang dapat digunakan pada ternak unggas adalah inulin yang berasal dari tanaman seperti umbi dahlia.Umbi bunga dahlia merupakan tanaman yang mengandung inulin 69,50 sampai 75,48\% dari karbohidrat(Saryono et al., 1998).Inulin merupakan "makanan" yang sesuai bagi pertumbuhan dan perkembangan bakteri yang menguntungkan di dalam usus seperti misalnya jenis bakteri asam laktat. Inulin merupakan dietary fiber yang mudah larut dalam air sehingga dapat difermentasi oleh Bifidobacteria dan Lactobacillus. Penggunaan probiotik seperti bakteri asam laktat (BAL) diharapkan menghasilkan antimikrobia yang bersifat antagonis terhadap pertumbuhan bakteri patogen dan memperbaiki keseimbangan bakteri menguntungkan didalam usus halus (Azhar, 2009).Bakteri yang umum digunakan sebagai probiotik yaitu Lactobacillus $s p$.yang dapat mempengaruhi peningkatan kesehatan karena dapat menstimulasi respon imun dan menghambat bakteri patogen (Kompiang, 2009).Lactobacillus $s p$. membutuhkan sumber "makanan"untuk dapat menghasilkan asam laktat dan short chain fatty acid (SCFA) sehingga dapat membantu menyehatkan saluran pencernaan. Dampak dari pemberian inulin bakteri menguntungkan lebih berkembang dan menekan pertumbuhan bakteri patogen. Mekanisme tersebut diatas menyebabkan kesehatan saluran pencernaan semakin baik dan penyerapan nutrien menjadi maksimal pada akhirnya berdampak pada produktivitas.

Fungsi probiotik umumnya selain mengatur keseimbangan mikroba dalam saluran pencernaan yang mendukung pertumbuhan, efisiensi penggunaan ransum serta mengoptimalkan penyerapan nutrien, kecuali lemak. Probiotik dalam penelitian ini berupa Lactobacillus sp.diharapkan dapat menekan metabolisme lemak pada ayam. Bakteri asam laktat khususnya 
Lactobacillus sp. diketahuimampu memproduksi enzim bile salt hydrolise (BSH) yang dapat mendekonyugasi garam empedu. Bile salt hydrolise $(\mathrm{BSH})$ mengakibatkan empedu terkonyugasi dan tidak dapat mengemulsikan lemak serta terbuang melalui ekskreta (Sunarlim, 2009)dalam Santoso (2013). Probiotik dapat menurunkan kadar lemak telur karena kemampuannya dapat memfermentasi karbohidrat dan menghasilkan asam lemak rantai pendek dalam saluran pencernaan. Pemberian probiotik dan prebiotik yaitu Lactobacillus sp. dan inulin dari umbi dahlia diharapkan dapat memanipulasi proses pencernaan lemak yang berkaitan dengan kualitas pertumbuhan dan produksi telur pada ayam Kedu.Penelitian ini bertujuan untuk mengetahui kecernaan lemak dan massa lemak telur ayam kedu periode petelur yang diberi ransum dengan tambahanLactobacillus sp.dan inulin dari umbi dahlia.

\section{METODE PENELITIAN}

Ternak yang digunakan dalam penelitian adalah ayam Kedu umur 7 bulan(awal bertelur) dengan rata-rata bobot badan awal $1300 \pm 229,92$ g sebanyak 80 ekor. Bahan penyusun ransum formula peternak terdiri dari jagung, bekatul, premix, konsentrat dan untuk ransum formula perbaikan terdiri dari jagung, bekatul, bungkil kedelai, tepung ikan, $\mathrm{CaCO}_{3}$, tepung tulang, cangkang kerang, premix, lisin dan methionin. Kedua jenis ransum tersebut diberi tambahan Lactobacillus sp. dan inulin dari umbi dahlia.Formulasi dan kandungan nutrisi ransum peternak dan perbaikan ditampilkanpada Tabel 1.

Pemeliharaan ayam selama 3 bulan dengan memberikan ransum perlakuan dari umur 7 bulan sampai umur 9 bulan. Pemberian ransum dilakukan dua kali sehari pada pagi dan sore hari. Kombinasi Lactobacillus sp.1,2 $\mathrm{ml}$ dan inulin dari umbi dahlia 1,2\%diberikan pada pagi hari dengan mencampur sebagian kecil ransum (20-30gram) secara homogen untuk menjamin agar dapat dikonsumsi habis seluruhnya sesuai dengan perlakuan. Air minum diberikanadlibitum.

Tabel 1. Formulasi dan Kandungan Nutrisi

\begin{tabular}{|c|c|c|}
\hline Bahan pakan & Ransum Peternak & Ransum Perbaikan \\
\hline & \multicolumn{2}{|c|}{ 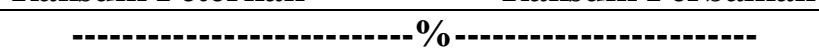 } \\
\hline Jagung & 36 & 50 \\
\hline Bekatul & 36 & 15 \\
\hline Bungkil kedelai & - & 22 \\
\hline Tepung ikan & - & 6,9 \\
\hline $\mathrm{CaCO}_{3}$ & - & 1,5 \\
\hline Tepung tulang & - & 0,5 \\
\hline Cangkang tulang & - & 3 \\
\hline Premix & 5 & 1 \\
\hline Konsentrat & 23 & - \\
\hline Lisin & - & 0,05 \\
\hline Methionin & - & 0,05 \\
\hline Total & 100 & 100 \\
\hline \multicolumn{3}{|l|}{ Kandungan Nutrien } \\
\hline Energi Metabolis** (kkal/kg) & 2585 & 2823 \\
\hline Protein Kasar* & 12,82 & 17,89 \\
\hline
\end{tabular}




\begin{tabular}{lcc}
\hline \multicolumn{1}{c}{ Bahan pakan } & Ransum Peternak & Ransum Perbaikan \\
\hline & $----------\cdot$ \\
\hline DL-Metionin*** & 0,27 & 0,42 \\
DL-Lisin*** & 0,83 & 1,06 \\
Arginin*** & 1,125 & 1,25 \\
Serat Kasar* & 7,58 & 3,95 \\
Lemak Kasar* & 2,28 & 2,28 \\
Kalsium* & 2,43 & 2,21 \\
Posphor* & 2,68 & 0,68 \\
\hline
\end{tabular}

Keterangan :

*Dianalisis di Laboratorium Ilmu Nutrisi dan Pakan, Fakultas Peternakan dan Pertanian, Universitas Diponegoro (2015).

**Berdasakan rumus perhitungan Balton (Siswohardjono,1982).

***Berdasarkan Tabel NRC (1998).

Tahap pengambilan data kecernaan lemak kasar dilakukan total koleksi ekskreta untuk pengukuran kecernaan lemak dengan penambahan indikator Pengukuran kecernaan lemak dengan indikator $\mathrm{Fe}_{2} \mathrm{O}_{3}$ sebanyak $0,5 \%$ dalam ransum, koleksi ekskreta dimulai ketika ekskreta mulai berubah warna dan dihentikan ketika ekskreta tidak berwarna seperti indikator yang diberikan. Sampel ransum dan sampel ekskreta kemudian ditimbang dan dikering udara, lalu dianalisis bahan kering dan kadar lemak kasarnya.Pengambilan data massa lemak telur dilakukan dengan cara menimbang bobot telur kemudian putih telur dan kuning telur dihomogenkan lalu dianalisis kadar lemaknya kemudian bobot telur tersebut dikalikan dengan kadar lemak telur. Sedangkan untuk pengambilan data lemak abdominal adalah dengan menimbang bobot lemak abdominal yang diperoleh dari proses pemotongan ayam Kedu.

Kecernaan lemak kasar $=$

(Kons.Ransum $x$ LK ransum) - (total ekskreta $x$ kadar LK ekskreta) (Kons.Ransum $x$ LK ransum)

Massa lemak telur

Massa lemak telur $=$ Berat telur $\mathrm{x}$ Kadar lemak telur

Lemak abominal $=\frac{\text { Bobot Lemak Abdominal }}{\text { Bobot Hidup }} \times 100 \%$

Rancangan yang digunakan dalam ransum perbaikan $+1,2 \mathrm{~mL}$ Lactobacillus penelitian ini yaitu rancangan acak lengkap $s p$ dan1,2\% inulin dari umbi dahlia.

(RAL) dengan 4 perlakuan dan 5 ulangan. Data hasil penelitian dianalisis Perlakuan terdiri dari $\mathrm{R} 1=$ ransum menggunakan analisis varians dengan peternak, $\mathrm{R} 2$ = ransum perbaikan, $\mathrm{R} 3=$ membandingkan nilai $\mathrm{F}$ hitung dengan $\mathrm{F}$ ransum peternak $+1,2 \mathrm{~mL}$ Lactobacillus $s p$ tabel pada taraf 5\%. Jika terdapat pengaruh dan1,2\% inulin dari umbi dahlia, $\mathrm{R} 4=$ akan dilanjutkan dengan uji Duncan untuk 
mengetahui perbedaan (Steel dan Torie, 1995).

\section{HASIL DAN PEMBAHASAN}

\section{Kecernaan Lemak}

Kecernaan lemak kasar pada perlakuan ransum peternak (T1) denganransum peternak + inulin dan Lactobacillus sp. (T3) sertaransum perbaikan(T2) dengan ransum perbaikan + inulin dan Lactobacillus sp. (T4) menunjukkan hasil yang tidak berbeda, karena tidak terjadi dekonjugasi garam empedu sehingga kecernaan lemak tidak berubah. Fenomena ini dapat diasumsikan pemberian probiotik tidak terjadi dekonjugasi dari pengaruh bile salt hydrolise (BSH) sehingga tidak mempengaruhi kecernaan lemak, karena pengaruh enzim lipase yang lebih dominan daripada bile salt hydrolise (BSH) berhubung umur ayam yang sudah tua.
Lima et al. (2003) menyatakan bahwa enzim lipase meningkat seiring dengan bertambahnya usia ayam. Berbeda halnya dengan penelitian sebelumnya dengan umur ayam yang lebih muda terjadi dekonjugasi garam empedu sehingga menurunkan kecernaan lemak. Fajrih (2014) melaporkan bahwa pada ayam dengan umur muda enzim bile salt hydrolise (BSH)dapat mendekonjugasi garam empedu, sehingga menurunkan kecernaan lemak.Perlakuan ransum perbaikan + inulin dan Lactobacillus sp. (T4) memiliki kecernaan lemak kasar paling tinggi karena keberadaan probiotik diduga belum mampu mempengaruhi aktivitas enzim bile salt hydrolise (BSH) untuk menurunkan kecernaan lemak.Sunarlim (2009) dalam Santoso (2013)menyatakan bahwa probiotik memproduksi enzim bile salt hydrolise (BSH) yang dapat mendekonyugasi garam empedu, akan tetapi pada penelitian ini belum terjadi.

Tabel 2. Kecernaan Lemak Kasar, Lemak Abdominal dan Massa Lemak Telur

\begin{tabular}{lcccc}
\hline \multirow{2}{*}{ Parameter } & \multicolumn{4}{c}{ Perlakuan } \\
\cline { 2 - 5 } & $\mathrm{T} 1$ & $\mathrm{~T} 2$ & $\mathrm{~T} 3$ & $\mathrm{~T} 4$ \\
\hline Kecernaan Lemak Kasar (\%) & $72,83^{\mathrm{b}}$ & $74,00^{\mathrm{ab}}$ & $72,09^{\mathrm{b}}$ & $76,92^{\mathrm{a}}$ \\
Lemak Abdominal (g) & 2,41 & 2,29 & 1,97 & 2,14 \\
Massa Lemak Telur (g) & $16,86^{\mathrm{a}}$ & $14,33^{\mathrm{b}}$ & $8,51^{\mathrm{d}}$ & $11,69^{\mathrm{c}}$ \\
\hline
\end{tabular}

Keterangan : Superskip pada baris yang sama menunjukkan perbedaan nyata $(\mathrm{P}<0,05)$.

\section{Lemak Abdominal}

Perlakuan ransum peternak (T1) dan ransum peternak dengan penambahan inulin $+\quad$ Lactobacillus sp. (T3) tidak menghasilkan perubahan lemak abdominal karena aktivitas probiotik tidak sampai pada deposisi lemak non hepatik dalam hal ini lemak abdominal, karena pada unggas metabolisme lemak non hepatik hanya 10\%. Ulupi dan Sumantri (2015) menyatakan bahwa lebih dari $90 \%$ sintesis lemak pada ayam adalah melalui jalur langsung (direct pathways) yang terjadi didalam hati, sedangkan kurang dari $10 \%$ sintesis lemak tubuh berlangsung di luar hati.Demikian pula dengan perlakuan perbaikan (T2) dan ransum perbaikan dengan penambahan inulin + Lactobacillus sp.(T4) tidak terjadi perubahan lemak abdominal. Seperti yang telah dibahas sebelumnya bahwa pemberian probiotik belum mampu menghasilkan enzim bile salt hydrolise (BSH) secara maksimal karena pengaruh enzim lipaseyang lebih dominan berhubung ayam yang digunakan sudah menjelang bertelur sehingga lemak 
abdominal yang dihasilkan sama. Lima et al. (2003) menyatakan bahwa enzim lipase meningkat seiring dengan bertambahnya umur ayam. Meningkatnya enzim lipase serta rendahnya kontribusi probiotik sehingga menyebabkan lemak yang dihasilkan sama. Aktivitas probiotik dalam saluran pencernaan seharusnya turut mempengaruhi rendahnya pembentukan lemak abdominal, namun pada penelitian ini proses tersebut tidak terjadi.

Timbunan lemak dalam tubuh ayam, termasuk lemak abdominal terjadi karena energi yang merupakan hasil dari proses metabolisme nutrisi yang masuk ke dalam tubuh ayam melebihi tingkat kebutuhan yang diperlukan oleh tubuh itu sendiri, baik untuk hidup pokok maupun untuk berproduksi (Oktaviana dkk., 2010). Timbunan lemak abdominal juga dapat dijadikan indikasi pada penelitian ini bahwa pemenuhan energi tidak berlebihan. Data konsumsi energi padapenelitian ini adalah $\mathrm{T} 1=245,39 ; \mathrm{T} 2=251,42 ; \mathrm{T} 3=259,28 ;$ dan T4=262,14(Lampiran 6). Konsumsi energi diketahui mempengaruhi secara langsung timbunan lemak abdominal dalam tubuh ayam (Hidayat, 2015).

\section{Massa Lemak Telur}

Perlakuan ransum peternak (T1) dibandingkan dengan ransum peternak + inulin dan Lactobacillus sp. (T3) menghasilkan penurunan massa lemak telur karena probiotik dapat menekan sintesis enzim lipase dalam usus halus menjadi lebih kecil, sehingga menghasilkan massa lemak telur yang lebih rendah meskipun dengan kecernaan lemak yang tidak berbeda. Ini berdampak tidak langsung terhadap penurunan lemak total didalam kuning telur, yang memberikan arti bahwa inulin dan Lactobacillus sp.dapat mengurangi metabolisme lemak kedalam telur. Ljungh et al.(2005) menyatakan probiotik dapat menurunkan kadar lemak kuning telur karena kemampuannya dapat memfermentasi karbohidrat dan menghasilkan asam lemak rantai pendek dalam saluran pencernaan. Probiotik dalam penelitian ini Lactobacillus sp. menghasilkan asam laktat dan short chain fatty acid (SCFA). Short chain free fatty $\operatorname{acid}$ (SCFA) setelah diabsorpsi langsung ke portal vein menuju ke hati untuk proses sintesis lemak di sel hati, tepatnya di sitoplasma. Peran enzim yang berhubungan dengan lipogenesis sangat diperlukan. Enzim tersebut satu diantaranya dikenal dengan malic enzyme.Mekanisme lain yang berkaitan dengan penurunan lemak yaitu melalui perananshort chain fatty acid (SCFA). Inulin merupakan karbohidrat yang tidak bisa dicerna oleh hewan inang nonruminan, tetapi dapat difermentasi oleh mikroba saluran pencernaan seperti Lactobacillus sp. menjadi short chain fatty $\operatorname{acid}$ (SCFA) dalam bentuk asetat, propionat dan butirat. Menurut Heavy dan Rowland (2004) short chain fatty acid (SCFA) tersebut dapat diserap dan dimetabolisir oleh hati serta terlibat dalam regulasi metabolisme lemak. Proses regulasi lemak seperti tersebut diatas dapat dianalogikan dengan penelitian Fajrih (2014) bahwa penambahan inulin dapat menurunkan lemak daging, sehingga dapat diasumsikan bahwa pengaruh inulin juga dapat menurunkan lemak telur. Disamping itu, probiotik dapat menurunkan lemak karena secara efektif dapat menekan aktivitas enzim asetil KoA karboksilaseyaitu enzim yang berperan dalam meningkatkan laju sintesis asam lemak(Santoso et al., 1995).

Pemberian probiotik mempunyai peranan dalam penurunan massa lemak telur meskipun dengan kecernaan lemak yang samabaik pada perlakuan ransum 
perbaikan (T2) maupun ransum perbaikan + inulin dan Lactobacillus sp. (T4). Fenomena ini menunjukkan bahwa mobilisasi lemak dapat dihambat oleh probiotik karena adanya keterkaitan enzim asetil KoA karboksilase yang mengatur metabolisme lemak untuk telur. Ketersediaan dan deposisi akhir lemak dalam kuning telur berasal dari sintesis lemak di hati. Penelitian terdahulu menyatakan bahwa dalam proses sintesis lemak di hati, kaitannya dengan peran enzim malat yang sangat besar (Rosebrough et al., 2011).

\section{KESIMPULAN}

Kesimpulan penelitian adalah pemberian 1,2 $\mathrm{mL}$ Lactobacillus sp. dan $1,2 \%$ inulin dari umbi dahlia baik pada ransum peternak maupun ransum perbaikan mampu menurunkan massa lemak telur, meskipun dengan kecernaan lemak sama.

\section{DAFTAR PUSTAKA}

Azhar, M. 2009. Inulin sebagai prebiotik. J. Scientec. 12(1):23-26.

Fajrih. 2014. Pemberian Umbi Bunga Dahlia (Dahlia variabilis) sebagai Sumber Prebiotik Inulin Kaitannya dengan Ketahanan Tubuh dan Profil Lemak pada Ayam Lokal Persilangan. Universitas Diponegoro, Semarang. (Tesis)

Heavey, P.M and I. R. Rowland. 2004. Review of role for short chain fatty acids in human health and desease.

J. European Nutrition Research 48: 124-141.

Hidayat, C. 2015. Penurunan deposit lemak abdominal pada ayam pedaging melalui manajemen pakan. Wartazoa 25 (3): 125-134.
Kompiang I. P. 2009. Pemanfaatan mikroorganisme sebagai probiotik untuk meningkatkan produksi ternak unggas di Indonesia. Pengembangan Inovasi Pertanian 2(3): 177 - 19.

Lima A.C.F, Pizauro Jr. JM, Macari M, Malheiros EB. 2003. Efeito do uso de probiótico sobre o desempenho e atividade de enzimas digestivas de frangos de corte. Rev. Bras.Zootecnia32(1):200-207.

Ljungh A., W. Torkel. 2005. Lacticacid bacteria asprobiotic: Current issue intestinal Microbiol. 7:73- 90.

Oktaviana D, Zuprizal, dan Suryanto E. 2010. Pengaruh penambahan ampas virgin coconut oil dalam ransum terhadap performans dan produksi karkas ayam broiler. Bul. Pet. 34:159-164.

Rosebrough, R.W., B.A. Russell, M.P. Richards. 2011. Furtherstudies on short-term adaptations in the expression oflipogenic genes in broilers. Comp. Biochem. PhysiolAMol. Integr. Physiol. 159 (1):1-6.

Santoso, A., N. Iriyanti dan S. T. Rahardjo. 2013. Penggunaan pakan fungsional mengandung omega 3, probiotik dan isolat antihistamin N3 terhadap kadar lemak dan kolesterol kuning telur ayam kampung. J. Ilmiah Pet. 1(3): 848-855.

Santoso, U., K. Tanaka, 1995. Effect of dried Bacillus subtilisculture on growth, body composition and hepatic lipogenic enzyme activity. Br. J. Nutr. 71: 523-529.

Saryono, Chainulfiffah, S. Devi, Monalisa, dan Dasli. 1998. Pemanfaatan umbi Dahlia variabilis untuk produksi sirup fruktosa dan fruktoologosarida (FOS). Seinar Nasional PBBMI XIV, Bandung. 
Steel, R. G. D dan J. H. Torrie. 1995.

Prinsip dan Prosedur Statistika.

Terjemahan B. Sumantri. Gramedia

Pustaka Utama, Jakarta.

Ulupi, N dan C. Sumantri. 2015. Peranan

kelompok gen triglyceride lipase, fatty acid synthase dan fattyacid binding protein pada metabolisme lemak ayam broiler. Wartazoa25 (1) :015-022. 